\title{
Stress Transfer Mechanism in 2D and 3D Unit Cell Models for Stone Column Improved Ground
}

\author{
K. S. Ng • S. A. Tan
}

Received: 2 November 2014 / Accepted: 24 November 2014/Published online: 12 December 2014

(c) Springer International Publishing AG 2014

\begin{abstract}
Stone column has been used widely to improve the foundation for many structures. Many designs of stone column are based on the unit cell concept. However, the intrinsic mechanism of stress transfer between the column and the surrounding soil has not been investigated thoroughly. This paper presents the important features of stress sharing mechanism in unit cell concept under an embankment loading. The arching effect, the deformation mode, the stress concentration ratio and the plastic straining in the unit cell are the main focus of this paper. Finite element software PLAXIS was used to examine these features. Unit cell was simulated as a two-dimensional (2D) axisymmetrical model and a representative three dimensional model in the numerical analysis. Drained loading condition was analyzed in this study in which the embankment is assumed to be built slowly with no excess pore pressure buildup. The change of the stress concentration ratio as the embankment height increases was also studied. From this study, it was found that the bulging happened near the column head accompanied by multiple shear bands progressing along the column. Generally, stone column in the unit cell shared about 4-5 times more the loads than the surrounding soils throughout the column depth. In most cases, 2D and 3D models give results that are similar to each other especially on the settlement performance and the failure mechanism.
\end{abstract}

\footnotetext{
K. S. $\mathrm{Ng}(\bowtie)$

Faculty of Civil Engineering, University Teknologi MARA, 13700 Permatang Pauh, Malaysia

e-mail: ngkokshien@ppinang.uitm.edu.my
}

\section{S. A. Tan}

Department of Civil and Environmental Engineering, University of Singapore, Singapore 119260, Singapore

e-mail: ceetansa@nus.edu.sg
Keywords Stone columns - Unit cell · Stress concentration ratio $\cdot$ Arching effect $\cdot$ Numerical analysis

\section{Introduction}

Stone column is a very popular ground improvement method to improve the subsoil condition. Its ability to increase the bearing capacity, reduce settlement and speed up the consolidation process has made it the top choices among the geotechnical experts when considering alternative solutions for soft soil problems. The method requires replacing of the weak subsoil with stiffer granular materials of typically $10-40 \%$. The application of stone column includes the road embankment, building foundations, bridge abutment, chemical or oil storage tanks and reservoir.

Most of the stone column designs have adopted the unit cell concept [1-6]. The unit cell model comprises a single stone column and its equivalent circular influence zone. It is used to represent a column located on the interior of an infinitely large group of stone columns. The idealization is made to simulate the case of rigid raft or large uniform loaded area as in the case of embankment supported on soft soils with uniformly spaced stone column group. The equivalent diameter for triangular, square and hexagonal arrangement of stone columns are $1.05 s, 1.13 s$, and $1.29 s$ respectively, where $s$ is the spacing of the columns [7].

Since the load and geometry are symmetrical in the unit cell, the boundary conditions at the outer wall are: zero shear stress, zero radial displacement, and no water flow [8]. Following these assumptions, total stress applied on the top of the unit cell must remain within the unit cell although the stress distribution between the column and the soil can be varied with depth [9]. Uniform loading applied 
over the unit cell is analogous to one dimensional (1D) consolidation test [10].

Since the stone column is stiffer than the native soil, concentration of stress occurs in the stone column with accompanying reduction of stress in the surrounding soil [11]. The stress concentration ratio, $n_{s}$ is the ratio of the stress in the column, $\sigma_{\mathrm{c}}$, to the stress in the soil, $\sigma_{\mathrm{s}}$. The stress distribution occurs when the settlement of the column and the surrounding soil is roughly equal. The stress concentration ratio is the most important factor in the unit cell concept. However, there is no rigorous solution available to give a rational estimate of this ratio, so that it has to be chosen either by empirical estimation on the basis of field measurements by means of load tests using earth pressure cells or from an engineer's experience. This ratio is important in predicting the beneficial effects of stone column reinforced ground especially in the settlement and stability analysis.

Aboshi et al. [11] proposed the average stress, $\sigma$ over the unit cell area corresponding to a given area replacement ratio as:

$\sigma=\sigma_{s} \alpha+\sigma_{c}(1-\alpha)$

Area replacement ratio $\alpha=A_{c} /\left(A_{c}+A_{s}\right)$, where $A_{c}$ and $A_{s}$ are cross-section areas of the column and the surrounding soil i.e. clay respectively. The stresses in the clay, $\sigma_{c}$ and stone column, $\sigma_{s}$ are given as:

$\sigma_{c}=\frac{\sigma}{\left[1+\left(n_{s}-1\right) \alpha\right]}=\mu_{c} \sigma$

$\sigma_{s}=\frac{n \sigma}{\left[1+\left(n_{s}-1\right) \alpha\right]}=\mu_{s} \sigma$

where $\mu_{c}$ and $\mu_{s}$ are the ratio of stresses in the column and clay, respectively, to the average stress, $\sigma$ over the tributary area.

Numerous publications have shown that the steady stress concentration ratio for stone column reinforced foundations is typically in the range of $2-6$, with the usual values of 3-4 [12-15]. On the other hand, Greenwood [16] reported a much higher ratio, i.e. $n_{s}=25$ being measured in very soft clay at low stress level. The effect of applied loading on the stress concentration ratio has been examined by some researchers. $\mathrm{Ng}$ [17] reported a very small increase in the $n_{s}$ as load increases, i.e. $n_{s} \approx 3.9$ to $n_{s} \approx 4$ for $q=50 \mathrm{kPa}$ to $q=400 \mathrm{kPa}$. Ichmoto [18] and Kim [19] drew the same conclusions while other researchers like Watts et al. [20] reported the increase of the stress concentration ratio due to the increase of loads based on a field load test but Bergado et al. [21] suggested the opposite trend.

This paper focuses on the load transfer mechanism between the column and the soil in the unit cell model. The change of stress concentration ratio with load is also examined. This paper also highlights the differences in the results for two dimensional (2D) and three dimensional (3D) numerical models.

\section{Numerical Model and Analysis}

In this study, a problem where stone column is used to support a large embankment was investigated. The columns were installed in a square grid with spacing, $s=1.5 \mathrm{~m}$ supporting an embankment of $5.0 \mathrm{~m}$ high. The $10.0 \mathrm{~m}$ long column was fully penetrating and resting on a rigid stratum. The column diameter is fixed at $0.85 \mathrm{~m}$ and the area replacement ratio, $\alpha$ was calculated to be 0.25 . Numerical analysis was performed using the finite element program PLAXIS 2D 2012 and PLAXIS 3D 2011. The 2D axisymmetric model using 1164 15-node triangular elements was built with equivalent diameter, $D_{e}$ of $1.70 \mathrm{~m}$. While in 3D analysis, a representative unit cell consists of 11432 10-node tetrahedral elements. Mesh sensitivity studies were performed to ascertain that the mesh was fine enough to give reliable results for the models concerned. Roller boundaries were used for the sides and fixed both horizontally and vertically for the bottom boundary. The phreatic level was set at the top surface. Figure 1 shows the 2D and 3D models used in the analysis.

The hardening soil (HS) model was chosen in this study. The HS model is an advanced elasto-plastic hyperbolic type model which is capable of capturing both the compression and shear hardening [22]. The HS model adopts Mohr-Coulomb failure criterion and the yield surface can expand due to plastic strains. The material properties of the unit cell model are shown in Table 1 . The friction angle of stone column, $\phi_{\mathrm{c}}^{\prime}$ was taken as $45^{\circ}$ with non-associated flow rule $(\psi=0)$. The value of dilation angle, $\psi$ is less certain since it is much affected by the confining stress of the surrounding soil and it is also very difficult to separate out the effect of high friction angle and dilation angle for an actual constructed stone column. To avoid numerical instability, the cohesion value of $0.1 \mathrm{kN} / \mathrm{m}^{2}$ was used. Typical soft soil stiffness, $E_{50}$ was adopted in this study. The columns stiffness parameters are more than ten times stiffer than the surrounding soil (reference pressure taken as $100 \mathrm{kN} / \mathrm{m}^{2}$ ) which is within the typical range. Barksdale and Bachus [9] stated that the typical elastic modulus ratio, $E_{c} / E_{s}$ of stone columns range from 10 to 20 , where $E_{c}$ is the Young's Modulus of the column, and $E_{s}$ is the Young's modulus of the soft soil. The HS model possesses the ability to capture the stress dependency of soil stiffness, and it is controlled by the parameter ' $m$ '. The value of $m=1$ is appropriate for the soft soil [23] but for the stone column, the $m$ value is an assumed value since it has not been measured before but probably between 0.3 and 0.5 . 


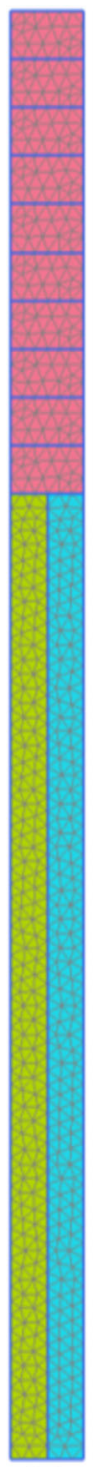

(a)

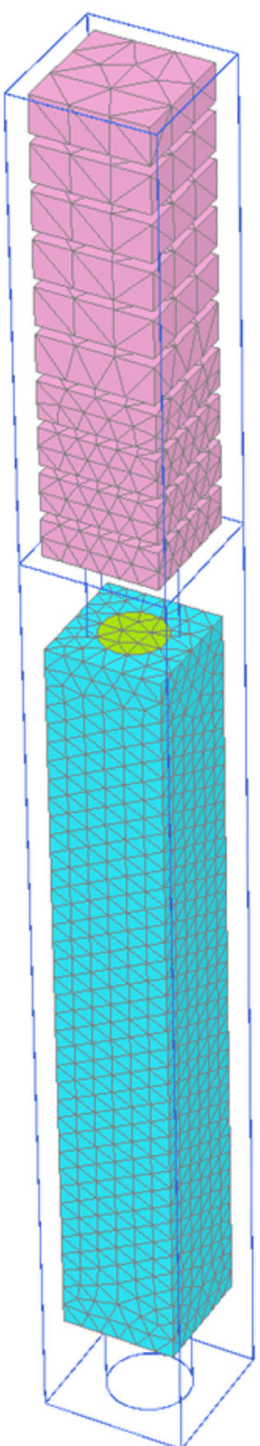

(b)
Fig. 1 Numerical models used in the analysis a 2D, and b 3D

Table 1 Material properties of unit cell models

\begin{tabular}{llll}
\hline Parameter & Stone column & Soft soil & $\begin{array}{l}\text { Embankment } \\
\text { fill }\end{array}$ \\
\hline$\gamma^{\prime}\left(\mathrm{kN} / \mathrm{m}^{3}\right)$ & 20 & 16 & 18 \\
$E_{50}^{\text {ref }}\left(\mathrm{kN} / \mathrm{m}^{2}\right)$ & 40,000 & 3,000 & 30,000 \\
$E_{\text {oed }}^{r e f}\left(\mathrm{kN} / \mathrm{m}^{2}\right)$ & 40,000 & 2,500 & 30,000 \\
$E_{\text {ur }}^{r e f}\left(\mathrm{kN} / \mathrm{m}^{2}\right)$ & 120,000 & 10,000 & 90000 \\
$c^{\prime}\left(\mathrm{kN} / \mathrm{m}^{2}\right)$ & 0.1 & 0.1 & 0.1 \\
$\phi^{\prime}\left({ }^{\circ}\right)$ & 45 & 25 & 35 \\
$v_{u r}(-)$ & 0.2 & 0.2 & 0.2 \\
$p^{\text {ref }}\left(\mathrm{kN} / \mathrm{m}^{2}\right)$ & 100 & 100 & 100 \\
$m(-)$ & 0.5 & 1 & 1 \\
\hline
\end{tabular}

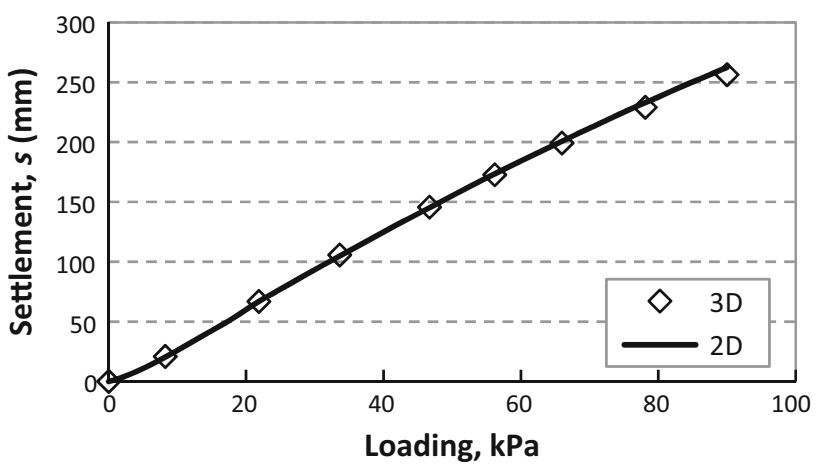

Fig. 2 Load-settlement curve for 2D and 3D models at centre of column

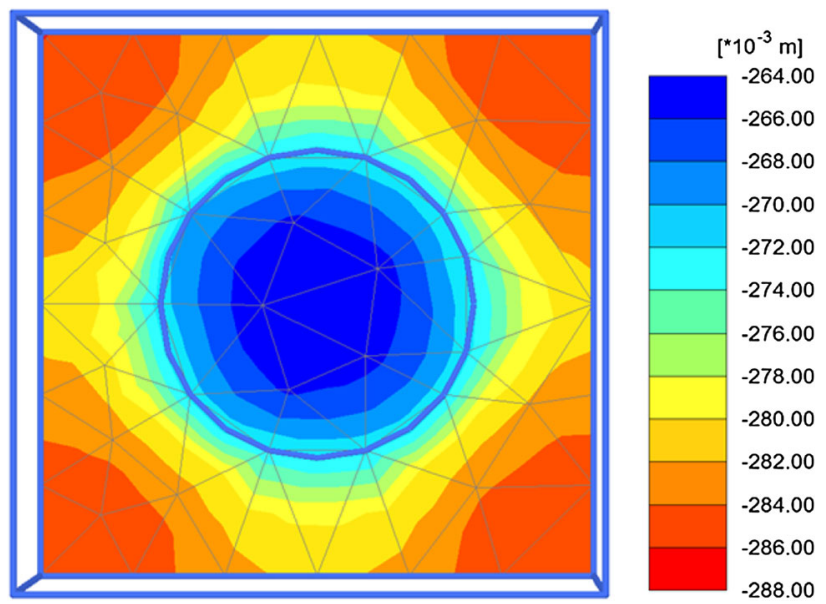

Fig. 3 Settlement shading for 3D model

The surrounding soft soil was assumed to be normal consolidated with OCR $=1.0$. Initial stresses were generated by $K_{o}$ procedure with the proposed value of lateral earth pressure, $K=1.0$ for both column and soil reflecting wishin-place approach adopted in the model. This approach has also been adopted by many researchers [24-26]. Drained analysis was performed in this study where the embankment fill was assumed to be constructed slowly and there was no excess pore pressure generation in the model.

\section{Results and Discussion}

\section{Settlement Performance}

The deformation behavior is first investigated. Figure 2 shows the settlement induced by the embankment loading. Excellent agreement is obtained for 2D and 3D models. The final settlement under $90 \mathrm{kPa}$ embankment loads is about $260 \mathrm{~mm}$ (measured at the centre of the column). Due to the nature of embankment loading, it is not a pure rigid condition but an 


\section{$x$-distance $(\mathrm{m})$}

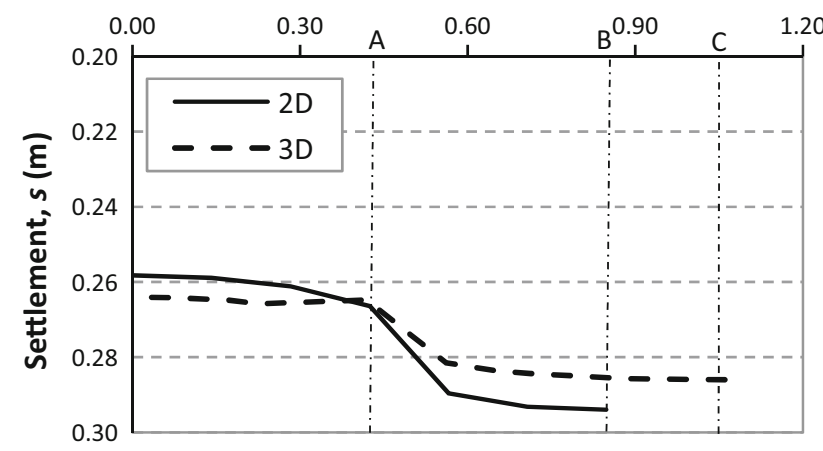

Fig. 4 Settlement profile at ground surface

intermediate between the 'equal strain' and 'free strain' state. This is observed when the settlement of the soft soil is more than for the column (about 20-30 mm) as shown in Figs. 3 and 4. Line A, B and C in Fig. 4 are the outer boundaries for the column, 2D model and 3D model respectively, in which the
$\mathrm{X}$-distance is measured from the centre of the column. Distance to $\mathrm{C}$ boundary is from the column's centre to the corner of the unit cell in the $3 \mathrm{D}$ model. The difference of results for $2 \mathrm{D}$ and $3 \mathrm{D}$ is very small $(<2 \mathrm{~mm})$ and in the practical point of view, the difference can be ignored.

Separate numerical analysis on the soft soil performance without stone column was carried out and the final settlement obtained was $594 \mathrm{~mm}$. This indicates that with stone column inclusion, the reduction of settlement is about $56 \%$ or equivalent to settlement improvement factor, $n$ of 2.3. Settlement improvement factor is the ratio of the settlement without improvement over the settlement with improvement. For comparison, calculation with Priebe [27] method gives final settlement improvement factor $n_{2}$ of 3.4 assuming constant stiffness for the columns, $E_{c}$ as $40,000 \mathrm{kN} / \mathrm{m}^{2}$ and soft soil, $E_{s}$ as $3,000 \mathrm{kN} / \mathrm{m}^{2}$. This is much higher than the value obtained in the present study. On the other hand, a simplified design method proposed by $\mathrm{Ng}$ and Tan [6] predicts $n$ equal to 2.3, a result similar to
Fig. 5 a Deformation mode, b incremental strain, and c horizontal displacement profile

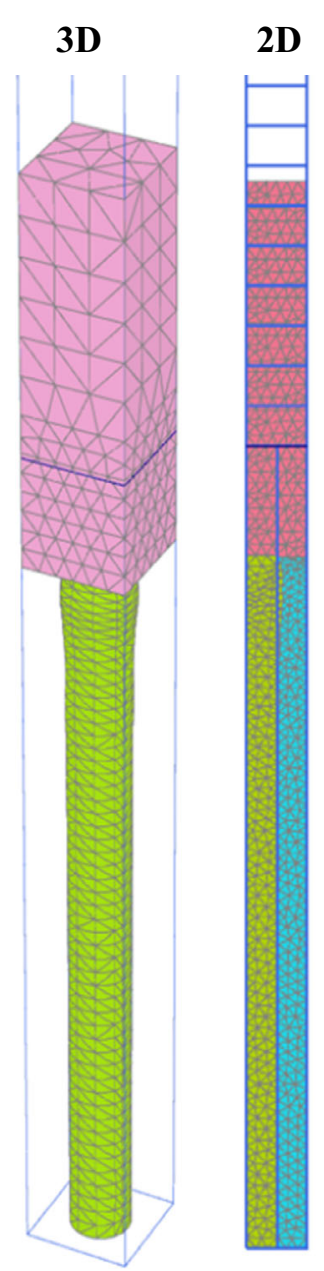

(a)

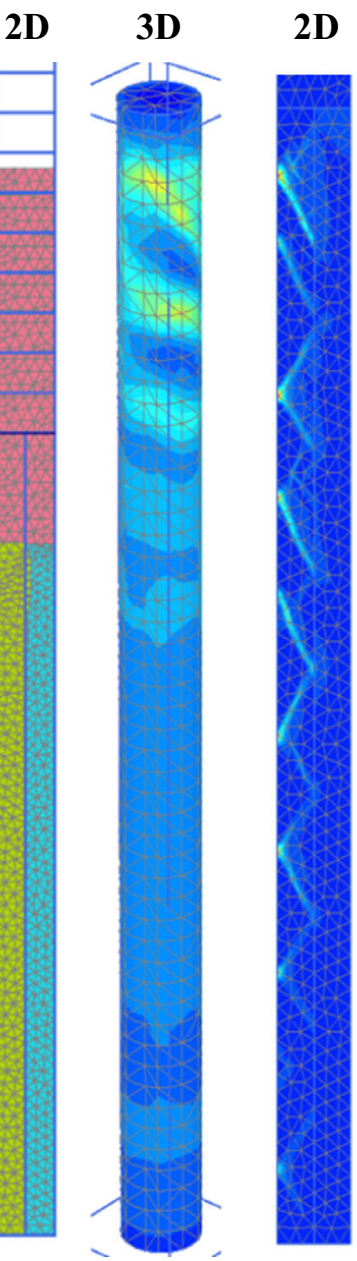

(b)

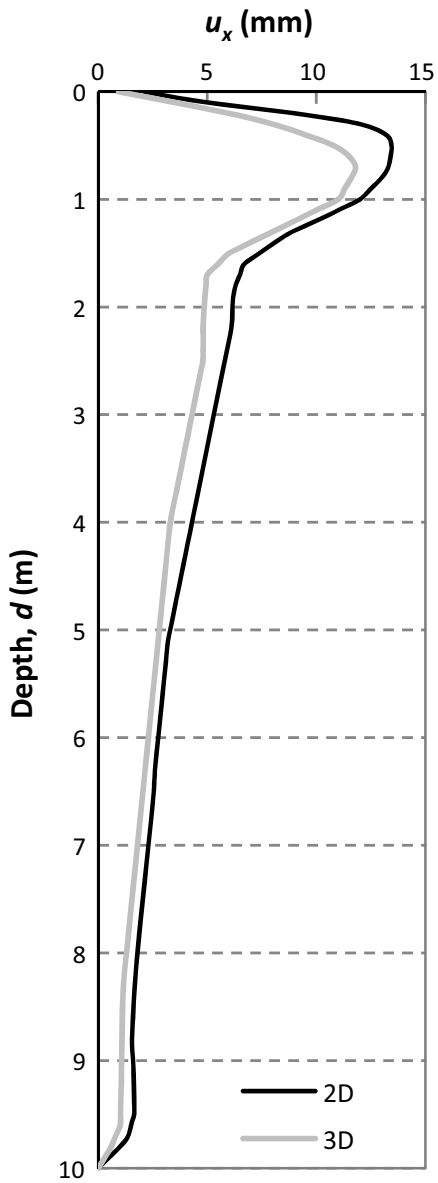

(c) 


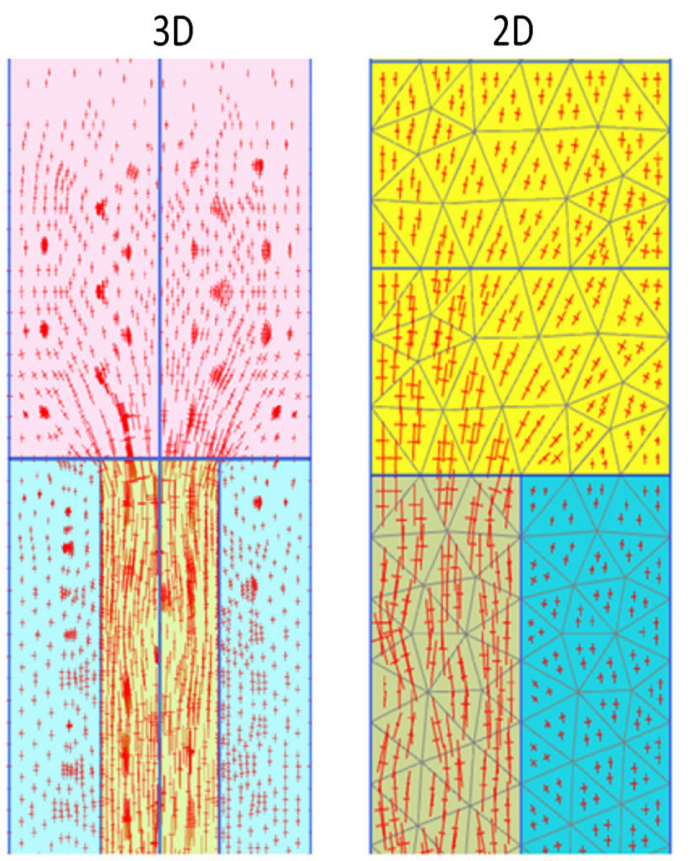

(a)

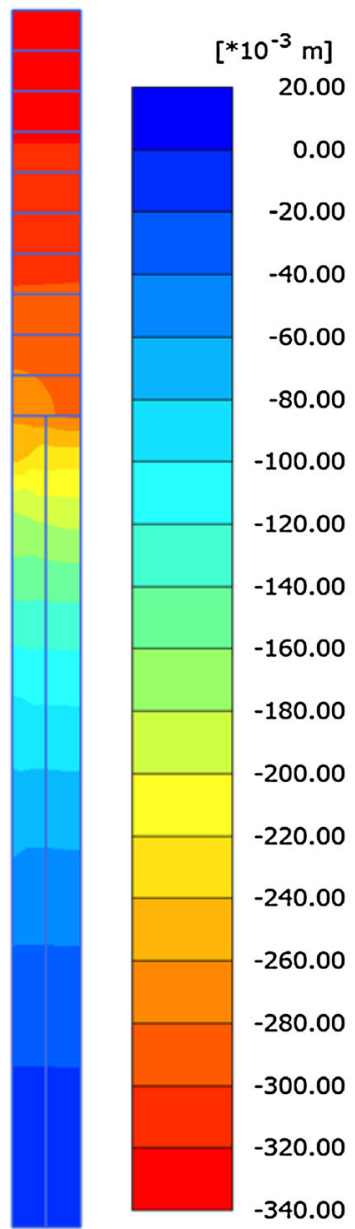

(b)

Fig. 6 a Orientation of principal stress, b total displacement shading this study. The method was developed from two dimensional numerical analysis using Mohr-Coulomb model for the soil materials in a unit cell. This method takes into accounts the influential parameters such as the column's length, column's friction angle, area replacement ratio, loading intensity and post installation lateral earth.

\section{Deformation Modes}

The deformation mode for stone column can be seen in Fig. 5a. Bulging is noticed in both the 2D and 3D models near the upper part of the column. The bulging of the stone column takes place when the applied load is higher than the confining stress. The surrounding soil provides some lateral support to prevent further expansion of the column. The confining stress increases with depth, so the bulging occurs in the upper part of the stone column [28]. Other than the bulging mode, multiple shear plane is found in the column with the initial shear band develops at the edge of the column and inclined toward the centre forming a shear cone (Fig. 5b). The shear band developed at $45^{\circ}+\phi_{c}^{\prime} / 2$ (where $\phi_{c}^{\prime}$ is the friction angle of stone column) and extend downward with zip-zap pattern.

Horizontal displacement profile along the column edge depicted in Fig. 5c shows that the maximum displacement in 2D model is slightly larger and located slightly higher compared to 3D model. The magnitude of maximum bulging is less than $15 \mathrm{~mm}$ or about $3 \%$ radial strain in the column and it happens at $0.5 \mathrm{~m}$ below ground surface. Below that, the radial strains are small and may not be able to fully develop the passive resistance along the column. Few methods have been proposed to estimate the ultimate bearing capacity of the improved ground assuming full bulging along the column length by adopting cylindrical cavity expansion theory $[9,29,30]$. However, it is doubtful to use these methods for columns under wide spread loading since the failure has occurred in the upper part of the column before full passive resistance are mobilized in the lower part of the column. On the other hand, Priebe [27] also assume constant bulging along the column using cavity expansion theory to predict the settlement improvement factor. Again, observation in this study shows the bulging is not constant along the column length and this may be the reason for the overestimation in the settlement improvement factor obtained using Priebe's method.

\section{Load Transfer Mechanism}

In stone column supported embankment, arching in the embankment is an important mechanism for load transfer, results in less differential settlement on the surface. Figure 6a shows the principal stress due to an arching 
Fig. 7 Stress distribution in a 3D model, and $\mathbf{b} 2 \mathrm{D}$ model

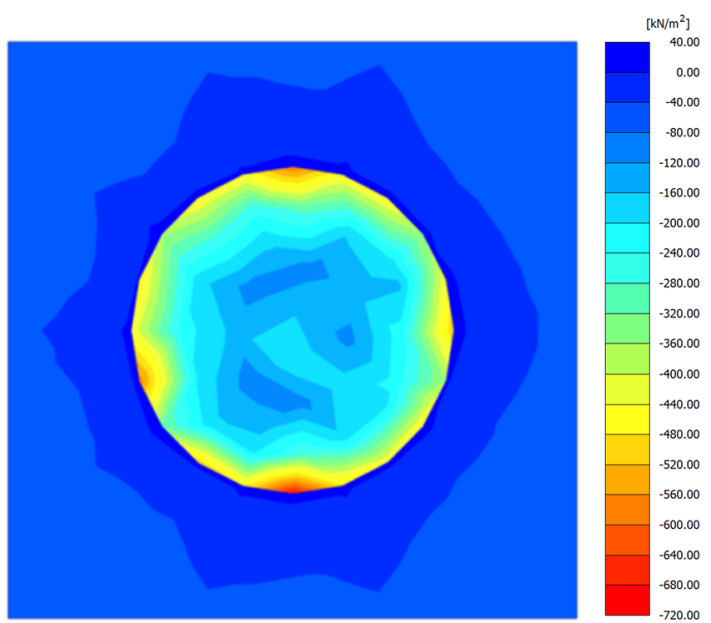

(a)

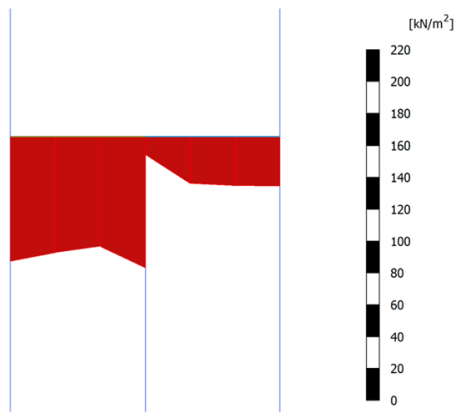

(b)
Fig. 8 a Stress concentration ratio profiles. b Stress increment profiles

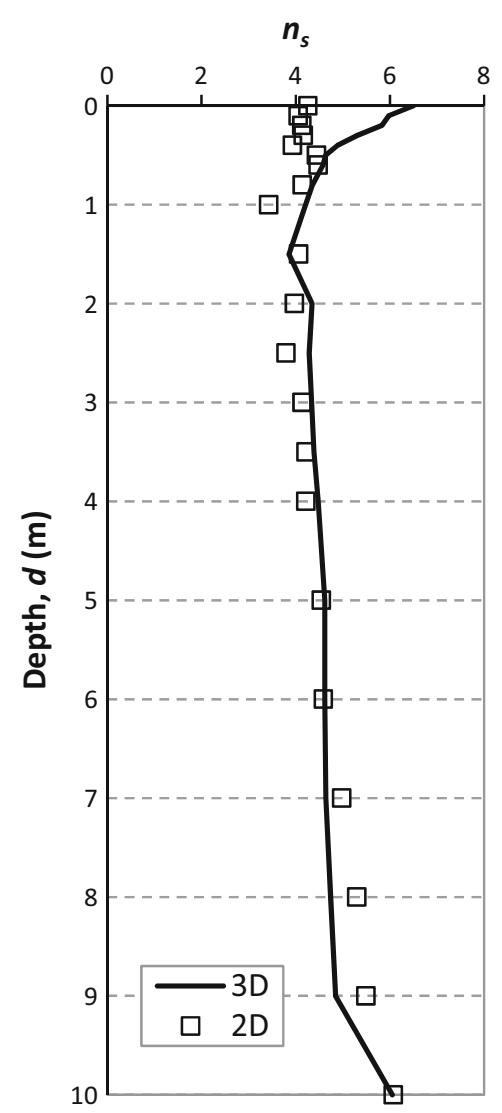

(a)

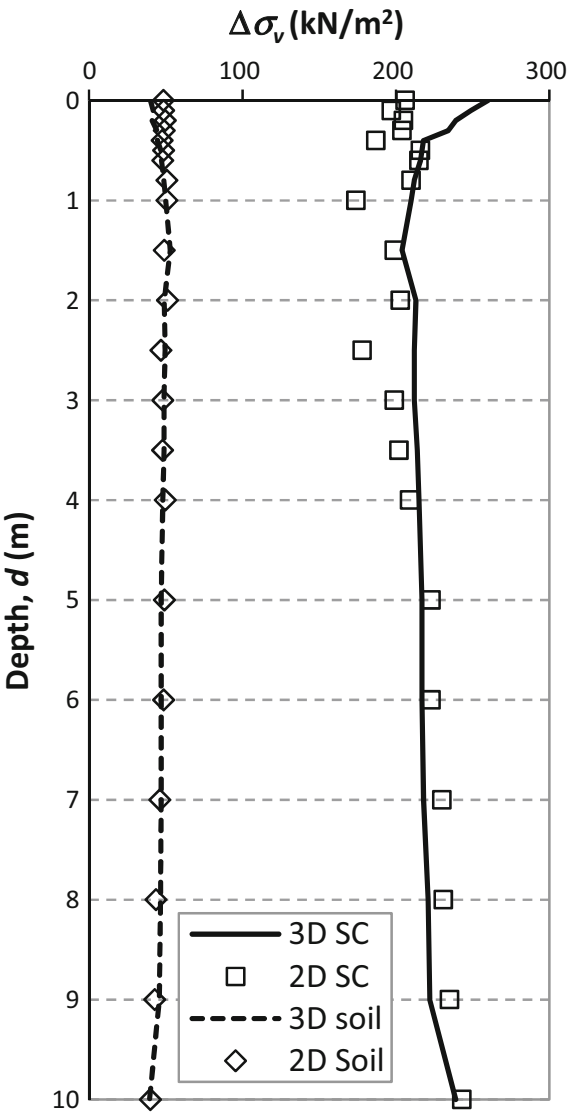

(b) effect where the stresses are redistributed. Arching initiates a reduction in the total stress on the soft soil but an increment on the column. The orientation of the principal stress shows inverse catenary-like shape arches. The arching height is roughly at $0.8 \mathrm{~m}$ for both $3 \mathrm{D}$ and $2 \mathrm{D}$ models. The arching height is much dependent on the flexibility of the embankment. Moreover, the differential vertical displacements in the embankment only occur up to a certain height, beyond that the uniform settlement can be seen as shown in Fig. 6b. Similarly, uniform settlement is also noticeable in the column and the surrounding soil at some distance below the ground surface. 
Through arching action, the embankment loads are largely transferred to the column due to high column's stiffness. Figure 7 shows the stress distribution in the unit cells for the 2D and 3D models at the ground surface. The stress concentration ratio, $n_{s}$ was calculated to be about 6.5 and 4.1 for $3 \mathrm{D}$ and $2 \mathrm{D}$ models respectively, which falls within normal range. The changes of the stress concentration ratio over depth are shown in Fig. 7a. There is a slight increment $\left(n_{s}=4-5\right)$ in this value for 2D model throughout the column depth (except at the column toe where $n_{s}=6.0$ was recorded) but a reduction in the value is noticed in $3 \mathrm{D}$ model near the column head to a point where $2 \mathrm{D}$ and $3 \mathrm{D}$ results coincide with each other and it increases slightly afterwards. It can be suggested that the stress concentration ratio of 4-5 may be a good value to be adopted in the design to predict the settlement of the embankment foundation.

At the depth of $5.0 \mathrm{~m}$ (referring to Fig. 8b), the 3D results gives the column stress, $\sigma_{c}$ of $217 \mathrm{kN} / \mathrm{m}^{2}$ and the soil stress, $\sigma_{s}$ of $48 \mathrm{kN} / \mathrm{m}^{2}$, while Eqs. 2 and 3 give $\sigma_{c}=218 \mathrm{kN} / \mathrm{m}^{2}$ and $\sigma_{s}=47 \mathrm{kN} / \mathrm{m}^{2}$ using $n_{s}=4.62$ (from 3D results). The good match of results has further validated the simple analytical method proposed by Aboshi et al. [11]. in calculating the average stress in the stone column and its surrounding soil. Figure 8 also shows higher stress concentration ratio at the column toe due to the remaining load that cannot shed along the side of the column.

Alamgir et al. [31] proposed an elastic method to predict the load sharing for the improved ground assuming 'free strain' condition in the unit cell. In their study, the stress concentration ratio was found to vary from unity at the surface and after that it increased non-linearly with depth up to the bottom. This finding is unacceptable since the stress concentration ratio is never a unity value measured on the ground surface based on the result obtained in the current study and also from the actual measurement at field and laboratory tests.

The yielding in the column with substantial Mohr-Coulomb points near the upper part was observed as shown in Fig. 9. Deeper along the column, the stress state in the column has not reached Mohr-Coulomb failure line but significant shear hardening (expanding shear locus) is occurred in the 2D and 3D models where 2D model indicates additional compressive hardening, a cap yield surface. On the other hand, no yielding is occurring in the soft soil as the stress state is still within the elastic region. The assumption made by Priebe [27] considering only plastic deformation for column and elastic deformation for surrounding soil could be true at least for the range of loading applied in the present study.

\section{Effect of Loading Stage}

In this study, the effect of loading stage was examined. The $5.0 \mathrm{~m}$ embankment was constructed in ten stages where each stage consists of $0.5 \mathrm{~m}$ embankment height, simulated

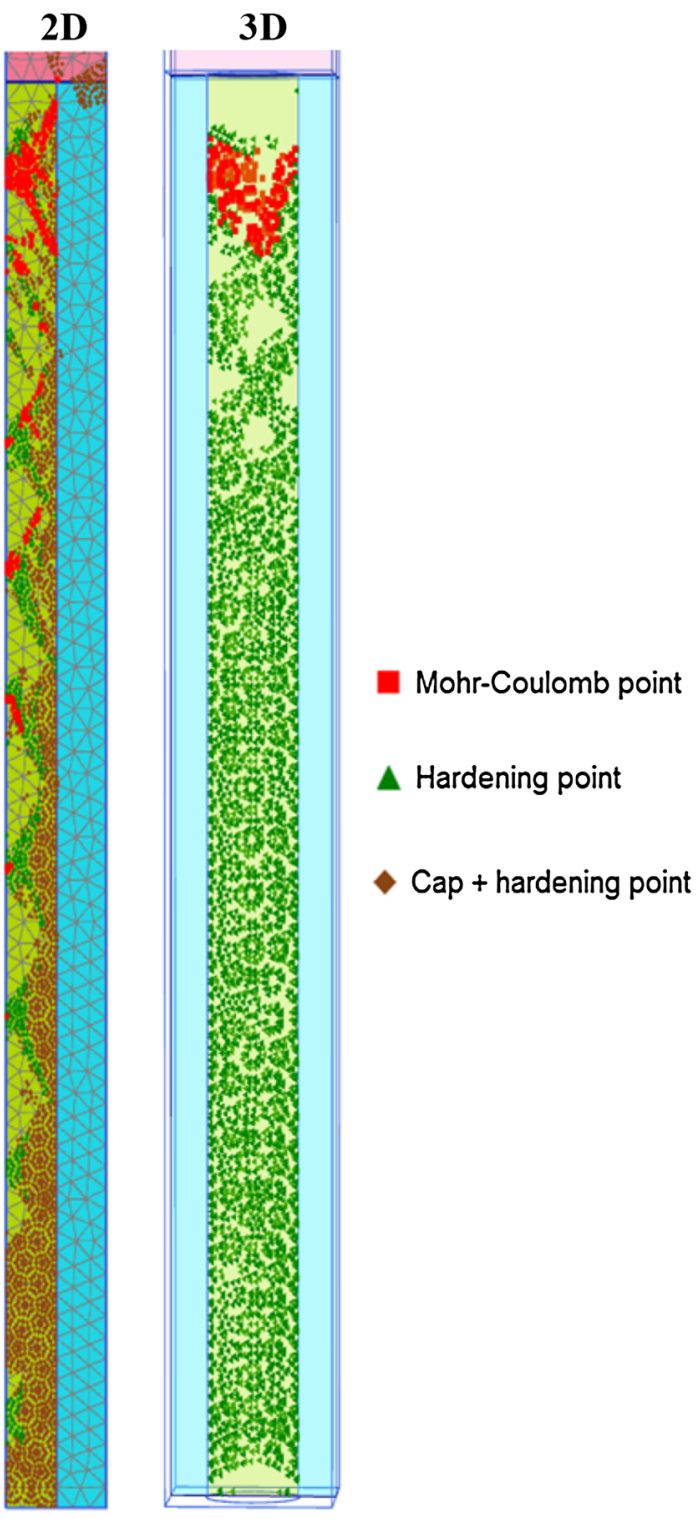

Fig. 9 Plastic points in the numerical models

in drained condition. The stress concentration ratio was measured at the ground surface and $5.0 \mathrm{~m}$ below the surface. Figure 10a shows that the 3D model gives overall higher stress concentration ratio than $2 \mathrm{D}$ models. The rate of increment in the stress concentration ratio is significantly higher in the early stage and stabilizes thereafter. This is due to the bulging and plastic straining that slowly developed until a state where a full lateral restraint and substantial yielding have achieved near the upper column. The kink in the 3D curve happened at stage 5 was not readily understood, possibly due to the shearing plane that cut through the column material that reduces the sustained load carried by the column.

Results of the stress concentration ratio, $n_{s}$ at depth $5.0 \mathrm{~m}$ are the opposite compared to that of ground surface. 


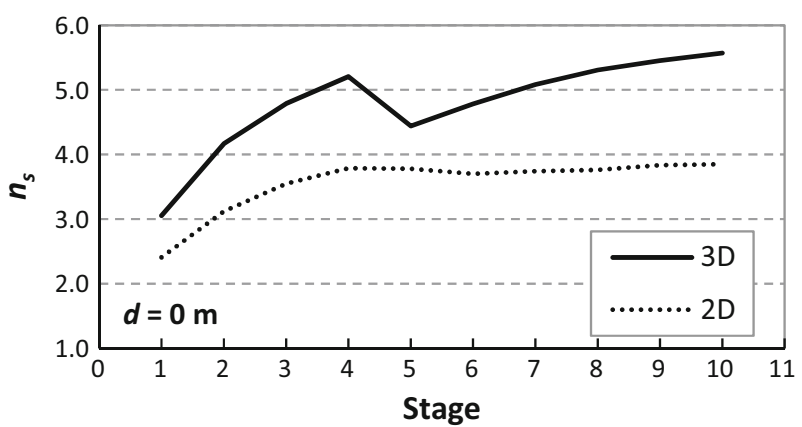

(a)

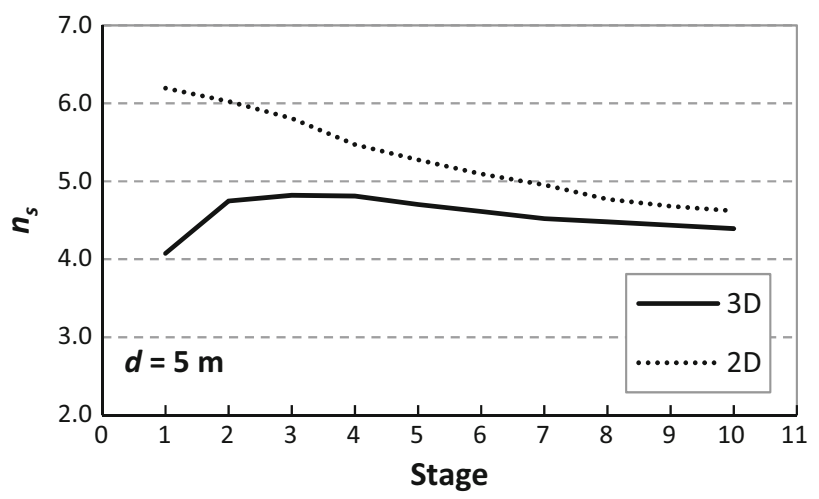

(b)

Fig. 10 Change of the stress concentration ratio with the increasing of embankment height at $\mathbf{a} d=0 \mathrm{~m}$, and $\mathbf{b} d=5.0 \mathrm{~m}$

Higher values are obtained for the $2 \mathrm{D}$ model than the $3 \mathrm{D}$ model as indicated in Fig. 10b. The 2D axisymetrical model takes advantage of the symmetry but sometimes the intrinsic mechanism such as the continuous shearing plane that occurred in the column as seen in the 3D model cannot be reproduced correctly by the axisymmetrical model. This roughly explains why there are differences in the 2D and $3 \mathrm{D}$ results. On the other hand, the increment of embankment height produces a reduced trend in the stress concentration ratios, more steeply in the $2 \mathrm{D}$ model than that in the $3 \mathrm{D}$ model. This phenomenon is also due to the increase of plastic straining in column, as explained in the above paragraph which reduces the proportion load sharing on the column. In the early stages of construction, the lower stress concentration ratio obtained at ground surface compared to the value at depth of $5 \mathrm{~m}$ may be attributed to the low surcharge at the beginning that has not caused the full arching effect to develop.

\section{Conclusion}

Numerical analysis was performed to investigate the load sharing mechanism between column and surrounding soil for unit cell in 2D and 3D models under drained condition.
In general, 2D model results agree very well with 3D model despite some discrepancy in the details. A few conclusions can be drawn from this study:

- Bulging is observed in the numerical models near the column head. Shear bands developed from the top of the column and progressing downwards.

- Soil arching reduces the vertical stress acting on the relatively soft soil while increasing the vertical stress acting on the stone column. Arching height is about $0.8 \mathrm{~m}$.

- The stress concentration ratios, $n_{s}$ for 3D and 2D models are 6.5 and 4.1 respectively at the ground surface. Generally, the stress concentration ratio increases with depth and the $n_{s}$ varied from 4 to 5 throughout the column's depth except at the column toe where the $n_{s}$ is about 6.0

- Stone column experiences substantial plastic straining compared to the surrounding soil where the stress state is still within the elastic region.

- Increment of embankment height results in the increase in the stress concentration ratio at the ground surface especially in the early loading stage. On the other hand, the stress concentration ratio at $5.0 \mathrm{~m}$ below the ground surface reduces when the embankment height increases.

\section{References}

1. Baumann V, Bauer GEA (1974) The performance of foundations on various soils stabilized by the vibro-compaction method. Can Geotech J 11(4):509-530

2. Van Impe WF, De Beer E (1983) Improvement of settlement behaviour of soft layers by means of stone columns. In: 8th international conference on soil mechanics and foundation engineering, Helsinki, pp 309-312

3. Madhav MR, Van Impe WF (1994) Load transfer through a gravel bed on stone column reinforced soil. J Geotech Eng ASCE 24(2):47-62

4. Indraratna B, Basack S, Rujikiatkamjorn C (2012) Numerical solution of stone column-improved soft soil considering arching, clogging, and smear effects. J Geotech Geoenviron Eng 139(3):377-394

5. Han J, Ye SL (2001) Simplified method for consolidation rate of stone column reinforced foundations. J Geotech Geoenviron Eng 127(7):597-603

6. Ng KS, Tan SA (2014) Floating stone column design and analyses. Soil Found 54(3):478-487

7. Balaam NP, Booker JR (1981) Analysis of rigid rafts supported by granular piles. Int J Numer Anal Meth Geomech 5(4):379-403

8. Castro J, Sagaseta C (2009) Consolidation around stone columns. Influence of column deformation. Int $\mathrm{J}$ Numer Anal Method Geomech 33(7):851-877

9. Barksdale RD, Bachus RC (1983) Design and construction of stone columns. Federal Highway Administration Office of Engineering and Highway Operations

10. Bergado DT, Anderson LR, Miura N, \& Balasubramaniam AS (1996) Granular piles. Soft ground improvement in lowland and other environments, ASCE Press, New York 
11. Aboshi H, Ichimoto E, Enoki M, Harada K (1979) The "Compozer"-a method to improve characteristics of soft Clays by inclusion of large diameter sand columns. In: Proceeding, international conference on soil reinforcement, pp 211-216

12. Goughnour RR, Bayuk AA (1979) A field study of long term settlements of loads supported by stone columns in soft ground. In: Proceeding, international conference on soil reinforcement, pp 279-286

13. Mitchell JK, Huber TR (1985) Performance of a stone column foundation. J Geotech Eng 111(2):205-223

14. Kirsch F, Sondermann W (2003) Field measurements and numerical analysis of the stress distribution below stone column supported embankments and their Stability. Workshop on Geotechnics of Soft Soils-Theory and Practice, Essen, pp 595-600

15. Ambily AP, Gandhi SR (2007) Behavior of stone columns based on experimental and FEM analysis. J Geotech Geoenviron Eng 133(4):405-415

16. Greenwood, DA (1991) Load tests on stone columns. In: Deep foundation improvements: design, construction and testing, pp 148-171

17. Ng KS (2014) Numerical study and design criteria of floating stone columns. Dissertation, National University of Singapore, Singapore

18. Ichmoto E (1981) Results of design and construction of sand compaction pile method. In: 36th JSCE conference discussion, pp 51-55

19. Kim TW (2001) Numerical analysis of the behavior of sand compaction pile in clay. Master thesis, Dankook University, (in Korean)

20. Watts KS, Serridge CJ (2000) A trial of vibro bottom-feed stone column treatment in soft clay soil. In: Proceeding, 4th international conference ground improvement geosystems, Helsinki, pp 549-556

21. Bergado DT, Panichayatum, Sampaco CL (1988) Reinforcement of soft bangkok clay using granular piles. In: Proceedings, international symposium on theory and practice of earth reinforcement, Kyushu, pp 179-184
22. Schanz T, Vermeer PA, Bonnier PG (1999) The hardening soil model: formulation and verification. In: Beyond 2000 in computational geotechnics, pp 281-296

23. Brinkgreve RBJ, Swolfs WM, Engin E, Waterman D, Chesaru A, Bonnier PG, Galavi V (2010) PLAXIS 2D 2010. User manual, Plaxis bv

24. Sexton BG, McCabe BA (2013) Numerical modelling of the improvements to primary and creep settlements offered by granular columns. Acta Geotech 8(4):447-464

25. Killeen MM, McCabe B (2010) A numerical study of factors affecting the performance of stone columns supporting rigid footings on soft clay. In: 7th European conference on numerical methods in geotechnical engineering, Taylor and Francis, pp 833-838

26. Gäb M, Schweiger HF, Kamrat-Pietraszewska D, Karstunen M (2008) Numerical analysis of a floating stone column foundation using different constitutive models. Geotechnics of soft soilsfocus on ground improvement. In: Karstunen and Leoni (ed) pp 137-142

27. Priebe HJ (1995) The design of vibro replacement. Ground Eng 28:31-37

28. Madhav MR, Miura N (1994) Soil improvement. Panel report on stone columns. In: Proceeding, 13th international conference on soil mechanics and foundation engineering, vol 5, New Delhi, pp 163-164

29. Vesic AS (1972) Expansion of cavities in infinite soil mass. J Soil Mech Found Div ASCE 98:265-290

30. Appendino M, Di Monaco F (1983) Use of the expanded cavity in columns group stability. Improvement of Ground. In Rathmayer HG, Saari KHO (eds) Proceeding, the 8th European conference on soil mechanic and foundantion engineering. Balkema, Rotterdam, pp 335-339

31. Alamgir M, Miura N, Poorooshasb HB, Madhav MR (1996) Deformation analysis of soft ground reinforced by columnar inclusions. Comput Geotech 18(4):267-290 